\title{
RETRO PERITONEAL SEMINOMA WITH OCCULT TESTICULAR PRIMARY DIAGNOSED BY FNAC - A CASE REPORT
}

\author{
Ramachandra V. Bhat ${ }^{1}$, Ramkumar Kurpad R²
}

HOW TO CITE THIS ARTICLE:

Ramachandra V. Bhat, Ramkumar Kurpad R. "Retro peritoneal seminoma with occult testicular primary diagnosed by FNAC - a case report". Journal of Evolution of Medical and Dental Sciences 2013; Vol2, Issue 34, August 26; Page: 6490-6493.

ABSTRACT: Germ cell tumors of the testis may present as a retroperitoneal mass without enlargement or any other symptoms of the testis. We hereby report a rare case of retroperitoneal seminoma with clinically normal testes, which was diagnosed by FNAC in a forty year old man. Presentation of testicular seminoma as retroperitoneal mass is rare. FNAC in this case proved to be very useful in identifying the nature of the mass and helped to detect the primary tumor.

KEY WORDS: Retroperitoneal seminoma, Occult primary, FNAC

INTRODUCTION: Germ cell tumors of the testis may present as a retroperitoneal mass without enlargement or any other symptoms of the testis. Primary in the testis may be just intratubular germ cell neoplasm or invasive germ cell tumor or burnt out primary. FNAC proves to be a simple, safe and rapid diagnostic tool in such cases like in many other superficial and deep-seated masses.

CASE SUMMARY: A forty year old man presented with backache of 2 months duration and mass per left upper part of abdomen of 20 days duration. On examination a mass was felt in the left hypochondriac and lumbar region. Surface was smooth and was firm in consistency. Clinically possibilities of lymphoma or retroperitoneal sarcoma were considered and USG and FNAC were asked. Routine investigations like blood counts and serum proteins were within normal limits.

Ultrasonography of abdomen showed lobulated, well-defined, mixed echogenic mass measuring $10 \mathrm{X}$ $6 \mathrm{X} 6 \mathrm{Cms}$. adjacent to aorta in the retroperitoneum. Other organs were normal. Ultrasound guided FNAC was done.

Cytological findings: Aspiration smears were cellular, show neoplastic cells having large nuclei containing 1-2 prominent nucleoli with clear or pale eosinophilic cytoplasm. The cells were seen singly and in focal small clusters. Lymphocytes were seen in between the tumor cells. Smudged nuclei, tigroid appearance and RBCs were seen in the background (Figure 1).

Cytological diagnosis of 'Seminoma' was made and advised to search for lesion in the testes. Subsequent USG examination of the testes revealed two small nodules in the left testis. Left testis with spermatic cord was excised.

Histopathological examination: Gross: specimen contained left testis with spermatic cord. Testis measured 3 X 2 X 2 Cms. External surface was normal. Cut section revealed two gray-white, well circumscribed nodules largest measured 0.5 X 0.5 Cms (Figure 2).

Microscopy: Section studied showed testicular tissue with seminiferous tubules showing focal atrophic changes and intratubular germ cell neoplasm component. The nodules showed round to 
oval neoplastic cells with clear cytoplasm. The tumors cells were separated by delicate fibrous septa, which were infiltrated by lymphocytes (Figure 3). Sections from the epididymis \& spermatic cord were free from tumor. Histopathological diagnosis of classical seminoma was made.

DISCUSSION: Approximately $1 \%$ of male patients with germ cell tumors present with retroperitoneal masses and clinically normal testes. ${ }^{1}$ Any type of germ cell tumor may be found in retroperitoneum, seminoma is the commonest, followed by embryonal carcinoma. ${ }^{2}$

In patients with retroperitoneal or disseminated germ cell tumors, histological studies of testis may show a palpable or occult germ cell tumor, intratubular germ cell neoplasia, or in absence of tumor, decreased spermatogenesis, peritubular or diffuse fibrosis, atrophy, calcification and scar tissue. ${ }^{3 \& 4}$ Coulier et al reported three cases where occult testicular seminoma mimicked primary extragonadal germ cell tumors ${ }^{5}$.Similarly occult seminoma may present with cervical lymphadenopathy due to metastasis ${ }^{6}$. However, primary retroperitoneal seminomas without evidence of testicular involvement were also reported. ${ }^{7}$ Careful examination of the testis and serial sections are to be done before ruling out possibility of metastasis because most of the retroperitoneal germ cell tumors have primary in testis ${ }^{8}$.

In our case two small nodules were seen in the left testis and histology revealed intratubular germ cell component and invasive seminoma.

\section{REFERENCES:}

1. Montague DK. Retroperitoneal germ cell tumors with no apparent testicular involvement. J Urol 1975; 113:505-08.

2. Kantoff PW, Esther O, Scully RE, Mark EJ, McNeely WF and Ebeling SH. Weekly clinicopathological exercises. Case 1-2000.NEJM 2000; 342:115-22.

3. Burt ME, Javadpour N. Germ cell tumors in patients with apparently normal testes. Cancer 1981; 47:1911-15.

4. Munro AJ, Duncem W, Webb JN. Extragonadal presentations of germ cell tumor. Br J Urol 1983; 55:440-44.

5. Coulier BY, Visscher LL, Bourgeois A, Montfort L, Clausse M, Mailleux P, et al. Metastases of clinically occult testicular seminoma mimicking primary extragonadal retroperitoneal germ cell tumors. JBR-BTR 2008; 91: 139-44.

6. Akst LM, Discolo C, Dipasquale B, Greene D, Roberts J. Metastatic seminoma with cervical lymphadenopathy as the initial manifestation. Ear Nose Throat J. 2004; 83:356-9.

7. Payombarnia SA, Safavi Sh, Azarpira N. Primary retroperitoneal seminoma: A case report. IRCMJ 2008; 10:127-30

8. Meares EM, Briggs EM. Occult seminoma of the testis masquerading as primary extragonadal germinal neoplasms. Cancer 1972; 30: 300-06. 


\section{CASE REPORT}

Figure 1. Large pleomorphic cells with indistinct cytoplasm. Background shows 'tigroid' appearance, smudged nuclei and lymphocytes. (MGG, X 400).

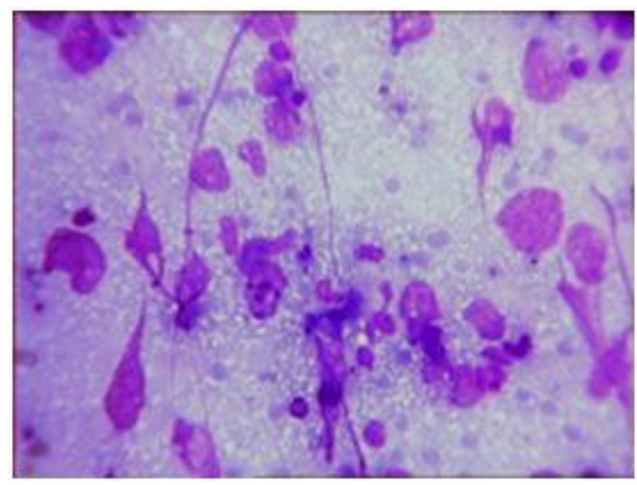

Figure 2. Orchidectomy specimen showing two grey white nodules.

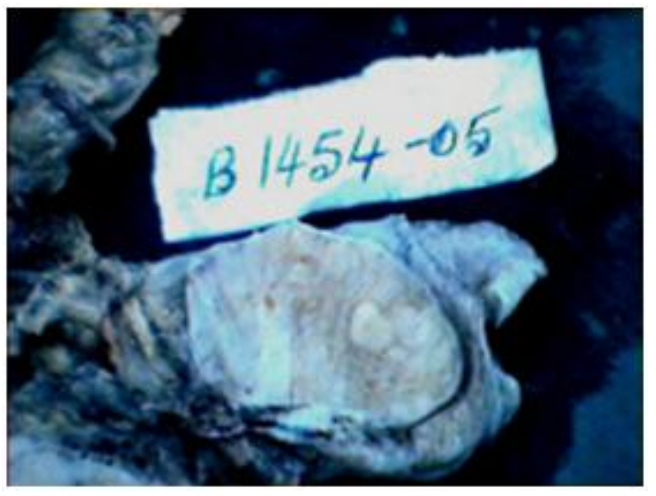

Figure 3. Tissue section showing seminoma cells with fibrous septa infiltrated by lymphocytes (H \& E, X 400).

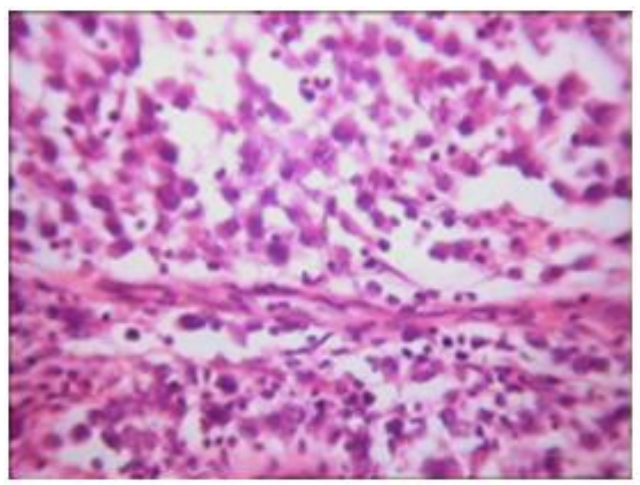




\section{AUTHORS:}

1. Ramachandra V. Bhat

2. Ramkumar Kurpad R.

\section{PARTICULARS OF CONTRIBUTORS:}

1. Professor, Department of Pathology, Indira Gandhi Medical College \& Research Institute, Kadirkamam, Pondicherry.

2. Professor and Head Pathology, DM WIMS, Naseera Nagar, Wayanad.

\section{NAME ADDRESS EMAIL ID OF THE} CORRESPONDING AUTHOR:

Dr. Ramachandra Bhat. V, Department of Pathology, Indira Gandhi Medical College, Kadirkamam, Pondicherry.

Email-rvbhatpath@yahoo.com

Date of Submission: 31/07/2013.

Date of Peer Review: 02/08/2013.

Date of Acceptance: 16/08/2013.

Date of Publishing: 22/08/2013 